\title{
$\alpha$-Amino Isobutyric Acid as a Constituent Amino Acid of Protein
}

\author{
(Studies on Muscle Proteins. Part 14)
}

Sir :

$\alpha$-Amino isobutyric acid as a constituent amino acid of protein was at first reported by $\mathrm{T}$. Yabuta ${ }^{1)}$ and his collabolates in 1938 and isolated as 5,5'-dimethylhydantoin in the dry distillate of pupae of silkworm.

Thereafter, few reports have appeared concerning this fact until Y. Oshima ${ }^{2)}$ et al. in 1953 recognized the presence of this amino acid in the acid-hydrolysate of casein by paper chromatography.

M. Kandatsu ${ }^{3)}$, one of the authors, confirmed the production of acetone from the acidhydrolysate of rabbit muscle proteins by the oxidation of hypochlorite and suggested its presence in the protein, because $\alpha$-amino isobutyric acid produces acetone exclusively by the oxidation of hypochlorite among known amino acids.

Continuing our investigations to clear up its presence in muscle protein, we could now

$\begin{array}{lc} & \text { Acid-hydrolysa } \\ \text { C }(\%) & 46.71 \\ \text { H } & 8.95 \\ \text { N } & 13.59 \\ \text { Sublimating point }\left({ }^{\circ} \mathrm{C}\right) & 275- \\ R_{F} \text { (phenol) } & 0.58 \\ \text { Picrate } & \\ \text { m.p. }\left({ }^{\circ} \mathrm{C}\right) & 194 \\ \text { C } & 36.61 \\ \text { H } & 4.11 \\ \text { N } & 16.82 \\ \text { Picrolonate } & \\ \text { m. p. } & 232-3 \\ \text { C } & 45.84 \\ \text { H } & 4.22 \\ \text { N } & 19.44 \\ & \\ \text { et al, Bulletin of the Institute of Physical and } & \\ \text { 17, 1241 (1938). } & \\ \text { et al, } J . \text { Agr. Chem. Soc. Japan., 27, 102 (1953). } \\ \text { Agr. Chem. Soc. Japan, 22, } 7(1948) .\end{array}$

1) T. Yabuta et al, Bulletin of the Institute of Physical and
Chemical Research, 17, 1241 (1938).
2) Y. Oshima et al, J. Agr. Chem. Soc. Japan., 27, 102 (1953).
3) M. Kandatsu, J. Agr. Chem. Soc. Japan, 22, 7 (1948). isolate this amino acid from both of the acidand pepsin-hydrolysates of horse muscle proteins which were prepared from the hind leg. A sample of $700 \mathrm{~g}$ of horse muscle proteins was hydrolysed by 10 -fold $20 \% \mathrm{HCl}$ solution under reflux for $20 \mathrm{hrs}$, then humin was filtered off, and concentration in vacuum repeated to remove as much $\mathrm{Cl}^{\prime}$ as possible. The hydrolysate was converted to copper salts with $\mathrm{CuCO}_{3}$ and $\mathrm{Cu}(\mathrm{OH})_{2}$ by the usual method.

The hydrolysate decomposed by enzyme was prepared from $100 \mathrm{~g}$ of muscle proteins by the usual method with concentrated pepsin at $\mathrm{pH} 2.0-2.2$ and $39^{\circ} \mathrm{C}$, for $40 \mathrm{hrs}$. and after adding $3 \% \mathrm{CCl}_{3} \mathrm{COOH}$ solution, the coagulants were filtered off. With the filtrate, copper salts were formed as described above.

The copper salts were fractionated with water and dry methanol, and the water soluble and methanol insoluble fractions were

$\begin{array}{cc}\begin{array}{c}\text { Pepsin- } \\ \text { hydrolysate }\end{array} & \begin{array}{c}\text { Calculated } \\ \text { for } \mathrm{C}_{4} \mathrm{H}_{9} \mathrm{NO}_{2}\end{array} \\ 46.06 & 46.60 \\ 8.07 & 8.74 \\ 13.86 & 13.60 \\ 281- & 280 \\ & 0.58 \\ 194 & 193-4 \\ & 36.14 \\ & 3.61 \\ & 16.87 \\ & 236 \\ & 45.78 \\ 4.63 \\ 19.07\end{array}$

collected.

After removal of copper by $\mathrm{H}_{2} \mathrm{~S}$, diamino and dicarboxylic acids were removed by 
phosphotungstic acid and $\mathrm{Ba}(\mathrm{OH})_{2}$-ethanol, respectively. The filtrate was again treated as mentioned above to form copper salts, then the water soluble and methanol insoluble fractions were collected. After the removal of copper, the mono-amino mono-carboxylic fraction was concentrated under vacuum and treated by silica-gel chromatography with phenol: $\mathrm{H}_{2} \mathrm{O}(8: 2)$. The elute which contained this amino acid only was shaken with ether to remove phenol and added with absolute ethanol to crystallize the amino acid.

By repetition of recrystallization with ethanol, about $140 \mathrm{mg}$ of white prismy crystalline was obtained. (Including about $20 \mathrm{mg}$ from enzyme hydrolysate)

The properties of this crystalline are summerized in the table.

The appearance of sublimation, results of elementary analysis, are consistent with thoretical values and m.p., elementary composition of picrate and picrolonate and also infra-red absorption spectrum of this amino acid are identical with a synthetic sample.

Accordingly, it is confirmed by us that $\alpha$ amino isobutyric acid is one of the constituent amino acids of the muscle protein.

The distribution of this amino acid in various proteins and its metabolism in higher animals is now under study.

Details of this experiment will appear in this journal.

Makoto KANDATsU Keiichiro KIKUNo

Department of Agricultural Chemistry, Faculty of Agriculture, University of Tokyo.

Received July 29, 1958 